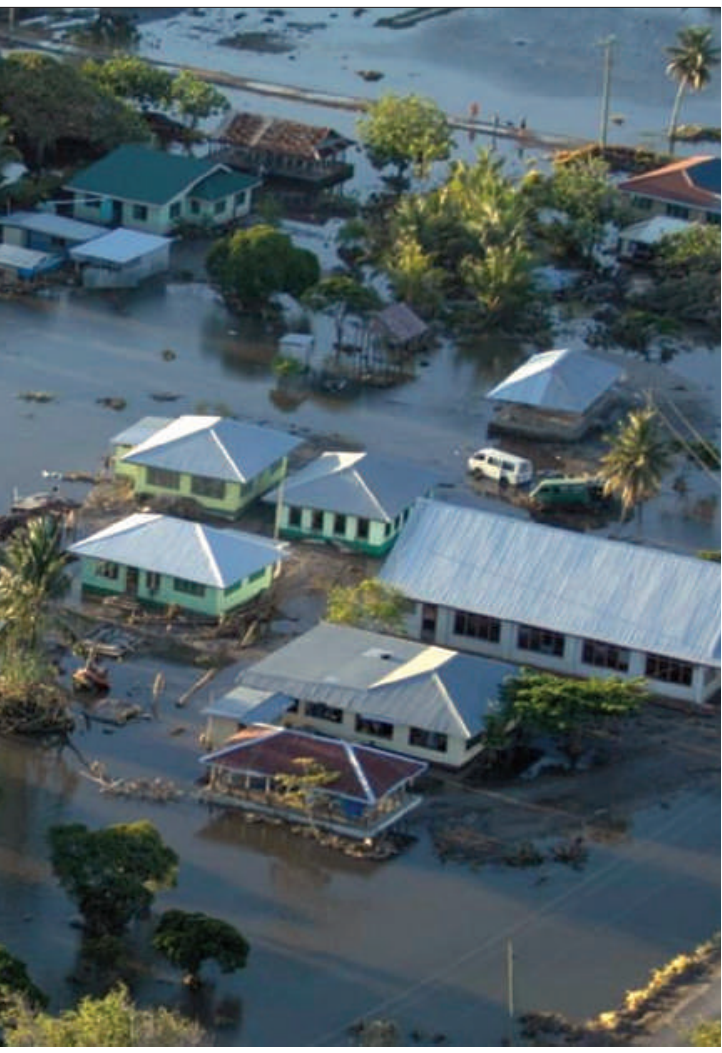

any tsunami, even if evacuation begins just minutes before the wave arrives. Regular drills are now conducted in some Javanese communities, but not all Indonesian coastlines are sufficiently prepared, says Spahn.

There have been some success stories in improving the communication of warnings down the critical 'last mile', he adds. For example, loudspeakers on mosques that normally call people for prayer are also an efficient way of broadcasting a tsunami warning, and have been used for this purpose in Sumatra and Java.

Similar public-education efforts paid off in saving lives in Samoa and American Samoa three months ago, says Bruce Jaffe, a coastalhazards researcher at the US Geological Survey in Santa Cruz, California. "Many people knew what to do," he says; they hurried on foot to higher ground.

The 2004 Indian Ocean tsunami, he says, provided "the wake-up call" to reinvigorate overall preparedness efforts for coastal communities around the world. But as more years pass since nearly a quarter of a million million people died, Jaffe worries that people's awareness will start to drop off again. "We can't let that happen," he says. "We've got to, if anything, step up the efforts."

Quirin Schiermeier, with additional reporting by Alexandra Witze

Jankaew, K. et al. Nature 455, 1228-1231 (2008)

2. Monecke, K. et al. Nature 455, 1232-1234 (2008).

3. Fritz, H. M. et al. Geophys. Res. Lett. 34, L12602 (2007).

I

ENCELADUS PLUME IS HALF ICE

Geysers not fed by misty water vapour after all. go.nature.com/Hpah3H

\title{
Extortion attempt involved retracted papers
}

Two papers retracted in the past few months have been linked to an extortion attempt. Both papers originated from the laboratory of Peter Schultz, a prominent chemist at the Scripps Research Institute in La Jolla, California.

Documents seen recently by Nature show that in 2007, law-enforcement officials in San Diego considered a former postdoctoral fellow from the Schultz lab as a possible suspect after another received an anonymous e-mail demanding a $\$ 4,000$ payment and threatening to reveal alleged fraud.

Law-enforcement officials did not pursue the case after the recipient of the e-mail decided not to press charges.

The retracted papers were published in Science ${ }^{1}$ and the Journal of the American Chemical Society $(J A C S)^{2}$. They claimed to describe the successful incorporation of amino acids linked to sugars at specific positions in proteins made by the bacterium Escherichia coli ${ }^{3}$.

On 1 March 2007, Zhiwen Zhang, the first author on the Science paper and the third author on the JACS paper, received an e-mail that read in part: "you have fraud on at least 3 papers and you stole library material- I found proof." The author of the e-mail asked Zhang to send cash to a post-office box in San Diego, and threatened that if Zhang did not comply, e-mails would be sent to Schultz, Scripps president Richard Lerner, and other scientists and administrators at Scripps and the University of Texas at Austin, where Zhang began working after he left the Schultz lab in 2004.

Zhang says he did not commit fraud. "I did no wrong, no scientific misconduct and no fraud," he says. "I am the victim of an extortion case, and I have suffered dearly."

The e-mail was forwarded to lawenforcement officials in San Diego. In March 2007, a southern California multiagency task force, the Computer and Technology Crime High-Tech Response Team, obtained warrants to search the records of Internet service providers in connection with the case. On 6 April, an officer with the task force notified Zhang that it considered Eric Tippmann, who overlapped with Zhang while both were postdoctoral fellows in Schultz's lab in 2004, to be a suspect. Zhang says that after consulting with Schultz and Lerner, he decided not to press criminal charges. Law-enforcement officials have confirmed that the investigation is closed.

Tippmann denies sending the extortion e-mail or contacting Zhang after Zhang left the Schultz lab. "If I was ever briefly mentioned in any investigation, I was never contacted nor interviewed, so this must have been a very short investigation," Tippmann wrote in an e-mail.

In August of this year, Tippmann and his colleagues published a study ${ }^{4}$ claiming that the experiments reported in the nowretracted papers could not have worked as described. Tippmann says he first became concerned about the papers in 2006 after he noticed what he alleges are similarities between mass spectra shown in the retracted JACS paper $^{2}$ and in an earlier JACS paper ${ }^{5}$ from the Schultz lab. Tippmann, now at Cardiff University, UK, says he also noticed other inconsistencies in some of the lab's papers, and flagged these to Schultz.

Zhang calls the issues raised by Tippmann "irrelevant". "It has all been cleared up," says Zhang, who says that Scripps has looked into the matter and cleared him of fraud and misconduct.

Schultz says that he has reproduced all of the results questioned by Tippmann, including other work that Zhang was involved in, except for the experiments that have now been retracted. He says that he is unsure why the mass spectra in the 2003 and 2004 JACS papers contain some similarities. "My guess is in that case a mistake was made," Schultz says. "I don’t think fraud was committed."

Zhang says that he stands by his original work.

Erika Check Hayden, with additional reporting by Rex Dalton

Zhang, Z. et al. Science 303, 371-373 (2004)

2. Xu, R. et al. J. Am. Chem. Soc. 126, 15654-15655 (2004)

3. Check Hayden, E. Nature 462, 707 (2009).

4. Antonczak, A. K., Simova, Z. \& Tippmann, E. M. J. Biol. Chem. 284, 28795-28800 (2009)

5. Alfonta, L., Zhang, Z., Uryu, S., Loo, J. A. \& Schultz, P. G. J. Am. Chem. Soc. 125, 14662-14663 (2003).

See go.nature.com/Innsou for a longer version of this story. 